\title{
In Streptococcus faecium Penicillin-binding Protein 5 Alone Is Sufficient for Growth at Sub-maximal But Not at Maximal Rate
}

\author{
By PIETRO CANEPARI, ${ }^{1}$ MARIA DEL MAR LLEÒ, ${ }^{1}$ GIUSEPPE \\ CORNAGLIA, ${ }^{2}$ ROBERTA FONTANA ${ }^{3 *}$ AND GIUSEPPE SATTA ${ }^{2}$ \\ ${ }^{1}$ Istituto di Microbiologia, Università di Genova, Genova, Italy \\ ${ }^{2}$ Istituto di Microbiologia e Virologia, Università di Cagliari, Cagliari, Italy \\ ${ }^{3}$ Istituto di Microbiologia, Università di Padova, Padova, Italy
}

(Received 6 August 1985)

\begin{abstract}
In Streptococcus faecium inhibition by both benzylpenicillin and cefotaxime of cells growing at maximal and at reduced rates was associated with saturation of different penicillin-binding proteins. Cells growing at reduced rates were not inhibited by benzylpenicillin concentrations that saturated all penicillin-binding proteins except penicillin-binding protein 5 , but did stop growing when this protein was saturated.
\end{abstract}

\section{INTRODUCTION}

An important step towards understanding the specific functions that penicillin-binding proteins (PBPs) perform in bacteria (Spratt, 1975; Tomasz, 1979; Matsuhashi et al., 1982; Waxman \& Strominger, 1983) would be the clarification of interactions between them and regulation of their activity in relation to the physiological status of the cells. From studies with $\beta$ lactam resistant mutants, several authors have suggested that certain PBPs can compensate for the loss of activity of others (Suzuki et al., 1978; Giles \& Reynolds, 1979; Brown \& Reynolds, 1980; Fontana et al., 1980, 1983a, b; Wyke et al., 1982; Hartman \& Tomasz, 1984) and the hypothesis has been proposed that function and activity of PBPs can vary depending on the physiological status of the cells (Fontana et al., 1983a). In this study we examine growth inhibition of Streptococcus faecium by both benzylpenicillin and cefotaxime.

\section{METHODS}

Bacterial strains and growth conditions. Streptococcus faecium PS is a penicillin susceptible strain used in previous studies (Fontana et al., 1980, 1983a, b). Streptococcus faecium R5, R20 and R40 are penicillin resistant mutants isolated from strain PS by serial culture in a medium containing increasing concentrations of penicillin (Fontana et al., 1983 b). Streptococcus faecium Rev 14 is a penicillin hypersusceptible strain, derived from strain R40, isolated after growth in the presence of novobiocin according to the procedure described by Eliopoulos et al. (1982) (Fontana et al., 1985).

Bacteria were grown in a chemically defined medium (CDM; Shockman, 1963) or in a yeast extract/peptone medium (SB; Fontana et al., 1983a). Growth was monitored in a Perkin-Elmer spectrophotometer.

Antibiotic and chemicals. $\left[{ }^{3} \mathrm{H}\right]$ Benzylpenicillin, ethylpiperidinium salt $\left(53.5 \mathrm{mCi} \mathrm{mg}^{-1} ; 1.98 \mathrm{GBq} \mathrm{mg}^{-1}\right)$ was a generous gift of the Merck, Sharp \& Dohme Research Laboratories, Rahway, NJ, USA. Penicillin G was provided by Eli Lilly and cefotaxime by Hoechst.

Chemicals for the preparation of polyacrylamide gels were obtained from Serva. All other chemicals were of analytical grade from Merck. Lysozyme, DNAase and RNAase were purchased from Sigma. For fluorography we used Kodak X-Omat SO 2825 X-ray film.

Susceptibility testing. Antimicrobial susceptibility was determined in CDM by a standard broth dilution technique. For a better correlation between growth inhibition and PBP binding experiments, a relatively high

Abbreviations: CDM, chemically defined medium; PBP, penicillin-binding protein. 
inoculum ( $10^{7}$ bacteria $\mathrm{m}^{-1}$, final density) of exponential phase organisms was used. MICs were determined by visual inspection for lack of turbidity after $18 \mathrm{~h}$ incubation at 30 or $45^{\circ} \mathrm{C}$ without shaking.

Studies of PBPs. Bacteria in early exponential growth phase were inoculated into batches of $\mathrm{CDM}\left(10^{7}\right.$ bacteria $\mathrm{ml}^{-1}$, final density) containing an appropriate $\beta$-lactam. Cultures were incubated for $60 \mathrm{~min}$ at 30 or $45^{\circ} \mathrm{C}$ without shaking. A sample containing approximately $4 \mathrm{mg}$ bacteria (dry weight) was taken, centrifuged $(3000 \mathrm{~g}, 10 \mathrm{~min})$, suspended in $100 \mu \mathrm{l} 10 \mathrm{mM}$-sodium phosphate buffer containing $\left[{ }^{3} \mathrm{H}\right]$ benzylpenicillin $\left(48 \cdot 5 \mu \mathrm{g} \mathrm{ml}^{-1}\right.$, final concentration) and incubated at the same temperature as was the culture before suspension. Control samples were preincubated in medium containing no antibiotic before exposure to the radioactive penicillin. Lysozyme, DNAase and RNAase were then added to the samples at final concentrations of $100 \mu \mathrm{g} \mathrm{ml}^{-1}, 5 \mu \mathrm{g} \mathrm{ml}^{-1}$ and $2.5 \mu \mathrm{g} \mathrm{ml}^{-1}$, respectively. Cell suspensions were incubated at the same temperature as used for growth until cell lysis occurred $(30 \mathrm{~min})$. The lysed cells were then resuspended in $10 \mathrm{ml}$ cold sodium phosphate buffer and membranes were pelleted at $100000 \mathrm{~g}$ for $60 \mathrm{~min}$ in a Beckman model $\mathrm{L}$ ultracentrifuge. Membranes were suspended in $50 \mu \mathrm{l}$ sample dilution buffer containing $0.2 \mathrm{M}$-Tris/ $\mathrm{HCl}$ buffer $(\mathrm{pH} 6.8), 3 \%(\mathrm{w} / \mathrm{v}) \mathrm{SDS}, 30 \%(\mathrm{v} / \mathrm{v})$ glycerol. $16 \%(\mathrm{v} / \mathrm{v})$ mercaptoethanol and $0.002 \%(\mathrm{v} / \mathrm{v})$ bromophenol blue and immediately heated to $100{ }^{\circ} \mathrm{C}$ for $2 \mathrm{~min}$. The sample was then applied to a polyacrylamide slab gel. Electrophoresis and PBP detection were done as described previously (Fontana et al., 1980, 1983a,b).

\section{RESULTS}

Fig. 1 and Table 1 show results of a typical competition experiment where growing cells were treated first with increasing concentrations of non-radioactive benzylpenicillin and then with a saturating concentration of the radioactive antibiotic. It was evident that in cells growing at the maximal rate (in $\mathrm{CDM}$ at $45^{\circ} \mathrm{C}$ ), a concentration of non-radioactive benzylpenicillin equal to the minimum inhibitory concentration (MIC) bound PBPs 1, 2 and 3, but completely saturated only PBP 3. This PBP was the only one that did not bind the radioactive benzylpenicillin added afterwards and did not appear in the fluorogram. In contrast, in cells growing in CDM at the sub-optimal temperature of $30^{\circ} \mathrm{C}$, concentrations of non-radioactive benzylpenicillin $\left(4 \mu \mathrm{g} \mathrm{ml}^{-1}\right)$, which caused virtually complete saturation of all PBPs except PBP 5, were not inhibitory and growth was inhibited only in the presence of the minimal antibiotic concentration needed to saturate completely PBP $5\left(8 \mu \mathrm{g} \mathrm{ml}^{-1}\right)$.

Previous studies with isolated membranes had shown that cefotaxime had a very low affinity for PBPs 4, 5 and 6 while showing an affinity similar to that of benzylpenicillin for all other PBPs (Coyette et al., 1983). Fig. 2 shows results of a typical competition experiment in which growing cells of $S$. faecium PS were treated first with increasing concentrations of nonradioactive cefotaxime and then with a saturating concentration of radioactive benzylpenicillin. As expected, in whole cells grown both at the maximal rate $\left(45^{\circ} \mathrm{C}\right)$ and at a reduced rate $\left(30^{\circ} \mathrm{C}\right)$ cefotaxime showed a very low affinity for PBPs 4, 5 and 6 (which it saturated at a concentration of $2000 \mu \mathrm{g} \mathrm{ml}^{-1}$ ) and an affinity for the other PBPs that was close to that of benzylpenicillin. The MIC of cefotaxime was very close to that of benzylpenicillin in cells growing at the maximal rate $\left(0.02\right.$ versus $\left.0.04 \mu \mathrm{g} \mathrm{ml}^{-1}\right)$, but in cells growing at the reduced rate it was 250 -fold higher (2000 versus $8 \mu \mathrm{g} \mathrm{ml}^{-1}$ ) (Table 2). At both temperatures PBPs 2 and 3 and PBPs 4,5 and 6 appeared to have the highest and the lowest affinity, respectively, for this antibiotic. PBPs 2 and 3 were saturated by a cefotaxime concentration equal to the MIC of the cells grown at the maximal rate, while PBPs 4, 5 and 6 were saturated by a concentration equal to the MIC for cells grown at a reduced rate (Table 2 ).

We have previously shown (Fontana et al., 1983b) that $S$. faecium strains resistant to benzylpenicillin overproduce PBP 5 and that in these strains this PBP is the only one necessary for cell growth. Table 2 shows that in these mutants resistance to benzylpenicillin and cefotaxime was equal in cells growing at 30 and $45^{\circ} \mathrm{C}$. The MIC of cefotaxime was much higher than that of benzylpenicillin and, in both cases, corresponded to the amount of antibiotic necessary to saturate PBP 5, while PBPs 4 and 6 were saturated at lower concentrations.

We have recently isolated and investigated the characteristics of the $S$. faecium Rev 14 mutant that is hypersusceptible to benzylpenicillin and which did not appear to synthesize any PBP 5 (Fontana et al., 1985). This strain showed a generation time very close to that of the parent at both 30 and $45^{\circ} \mathrm{C}$. Table 2 shows that the MICs of benzylpenicillin and cefotaxime for strain $\operatorname{Rev} 14$ were the same at both 30 and $45^{\circ} \mathrm{C}$. In addition the MICs were very close to that of strain 

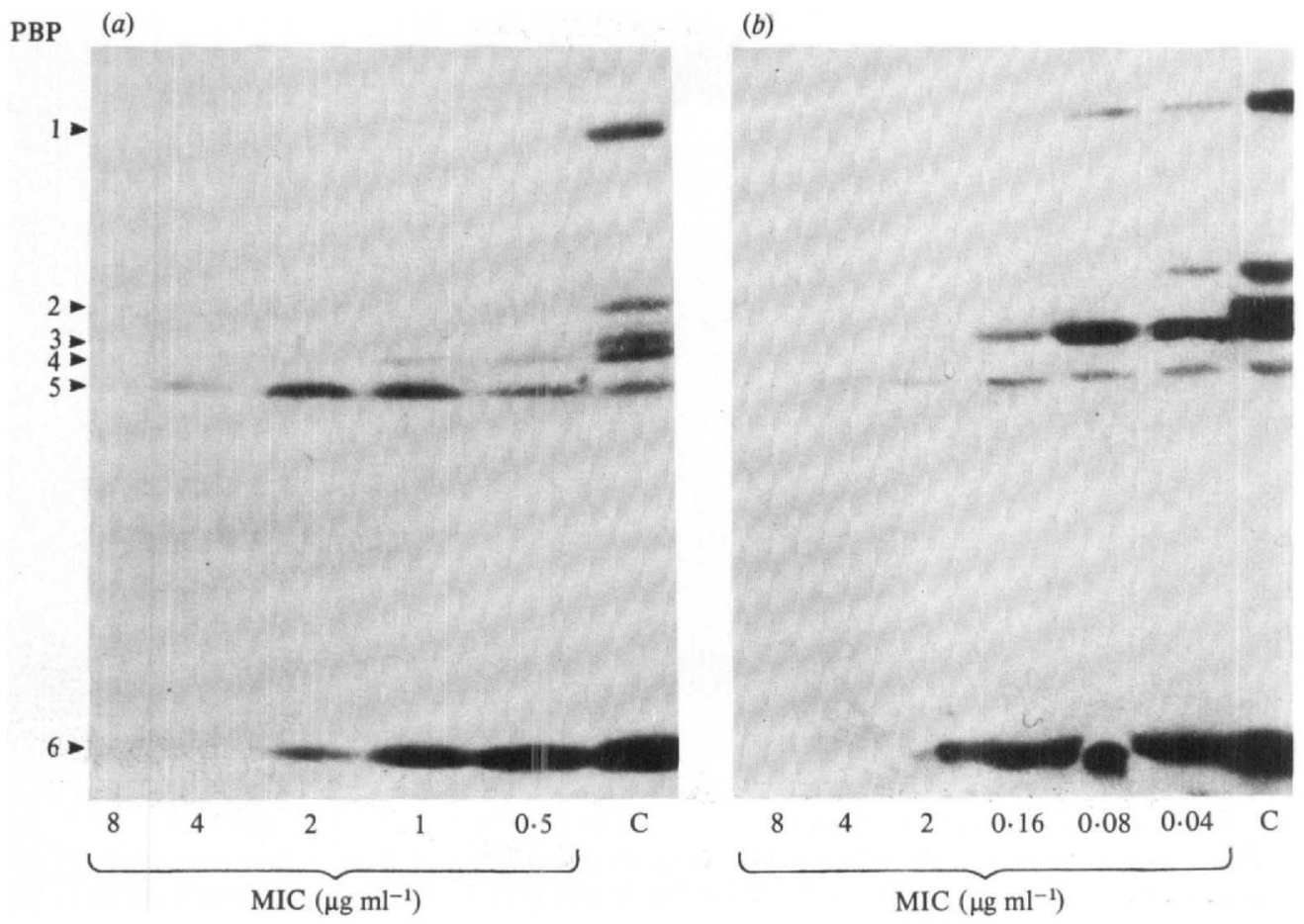

Fig. 1. Competition between non-radioactive and radioactive benzylpenicillin for binding to PBPs in whole cells of $S$. faecium grown at $30^{\circ} \mathrm{C}(a)$ and $45^{\circ} \mathrm{C}(b)$. Samples $(10 \mathrm{ml})$ of two exponential cultures, one growing at $30^{\circ} \mathrm{C}$ and the other at $45^{\circ} \mathrm{C}$, were treated for $60 \mathrm{~min}$ with non-radioactive benzylpenicillin at several concentrations. An additional sample was left untreated as a control (C). Cells were immediately harvested by centrifugation and PBPs were labelled and visualized as described.

Table 1. Benzylpenicillin MICs, generation times and extent of saturation of the various PBPs by non-radioactive benzylpenicillin in S. faecium PS grown in CDM at two different temperatures

The results are from the experiments represented in Fig. 1 and are the mean of three separate experiments. The amount of radioactivity bound to PBPs was estimated by microdensitometry of the fluorograms with a Joyce Loebl MK3CS densitometer.

\begin{tabular}{|c|c|c|c|c|c|c|c|c|c|}
\hline \multirow{2}{*}{$\begin{array}{l}\text { Growth } \\
\text { temp. } \\
\left({ }^{\circ} \mathrm{C}\right)\end{array}$} & \multirow{2}{*}{$\begin{array}{c}\text { Generation } \\
\text { time } \\
(\mathrm{min})\end{array}$} & \multirow{2}{*}{$\begin{array}{c}\text { MIC } \\
\left(\mu \mathrm{g} \mathrm{ml}^{-1}\right)\end{array}$} & \multirow{2}{*}{$\begin{array}{l}\text { Benzylpenicillin } \\
\text { concn } \\
\left(\mu \mathrm{g} \mathrm{ml}^{-1}\right)\end{array}$} & \multicolumn{6}{|c|}{ Percentage saturation of PBP: } \\
\hline & & & & 1 & 2 & 3 & 4 & 5 & 6 \\
\hline \multirow[t]{5}{*}{30} & 50 & 8 & $0 \cdot 5$ & 95 & 95 & 100 & 80 & 0 & 40 \\
\hline & & & 1 & 100 & 100 & 100 & 90 & 0 & 60 \\
\hline & & & 2 & 100 & 100 & 100 & 100 & 20 & 90 \\
\hline & & & 4 & 100 & 100 & 100 & 100 & 60 & 100 \\
\hline & & & 8 & 100 & 100 & 100 & 100 & 100 & 100 \\
\hline \multirow[t]{6}{*}{45} & 31 & 0.04 & 0.04 & 70 & 80 & 100 & 0 & 0 & 0 \\
\hline & & & $0 \cdot 08$ & 80 & 95 & 100 & 30 & 0 & 10 \\
\hline & & & $0 \cdot 16$ & 90 & 100 & 100 & 80 & 0 & 30 \\
\hline & & & 2 & 100 & 100 & 100 & 90 & 50 & 80 \\
\hline & & & 4 & 100 & 100 & 100 & 100 & 70 & 95 \\
\hline & & & 8 & 100 & 100 & 100 & 100 & 100 & 100 \\
\hline
\end{tabular}

PS growing at $45^{\circ} \mathrm{C}$ and corresponded to an antibiotic concentration that saturated PBP 3 alone in all strains at both temperatures (see also Fontana et al., 1980). This finding suggested that in the penicillin hypersusceptible strain the target for growth inhibition was the same under all the experimental conditions tested. Hence PBP 5 appeared to be necessary for $\grave{S}$. faecium cells to become more resistant to $\beta$-lactams when growing at a reduced rate. 


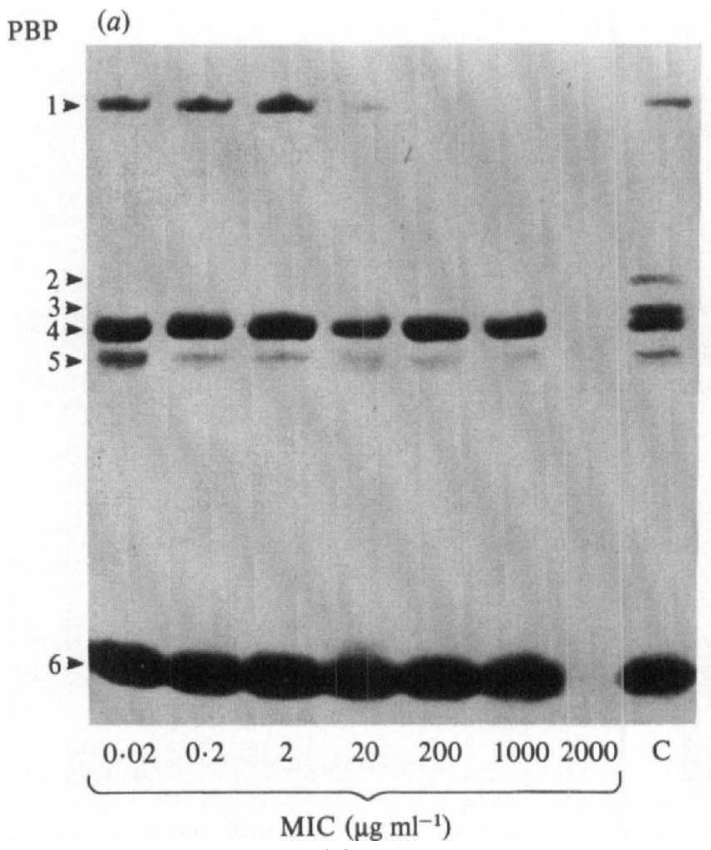

(b)

Fig. 2. Competition between cefotaxime and radioactive benzylpenicillin for binding to PBPs of $S$. faecium grown at $30^{\circ} \mathrm{C}(a)$ and $45^{\circ} \mathrm{C}(b)$. Experiments were done as described in the legend to Fig. 1 except that cefotaxime at various concentrations was used instead of non-radioactive benzylpenicillin.

Table 2. MICs for benzylpenicillin and cefotaxime, and concentrations required to saturate PBPs of S. faecium PS and penicillin resistant and hypersusceptible mutants grown at two different temperatures

The results are the mean of three separate experiments.

\begin{tabular}{|c|c|c|c|c|c|c|c|c|c|}
\hline \multirow[b]{2}{*}{ Strain } & \multirow{2}{*}{$\begin{array}{l}\text { Growth } \\
\text { temp. } \\
\left({ }^{\circ} \mathrm{C}\right)\end{array}$} & \multirow{2}{*}{$\begin{array}{c}\text { Generation } \\
\text { time } \\
(\mathrm{min})\end{array}$} & \multicolumn{2}{|c|}{$\operatorname{MIC}\left(\mu \mathrm{g} \mathrm{ml}^{-1}\right)$ for: } & \multicolumn{2}{|c|}{$\begin{array}{l}\text { Concn }\left(\mu \mathrm{g} \mathrm{ml}^{-1}\right) \\
\text { of benzylpenicillin } \\
\text { saturating PBP:* }\end{array}$} & \multicolumn{3}{|c|}{$\begin{array}{l}\text { Concn }\left(\mu \mathrm{g} \mathrm{ml}^{-1}\right) \text { of cefo- } \\
\text { taxime saturating PBP } \dagger\end{array}$} \\
\hline & & & $\begin{array}{l}\text { Benzyl- } \\
\text { penicillin }\end{array}$ & $\begin{array}{l}\text { Cefo- } \\
\text { taxime }\end{array}$ & 3 & 5 & 2 and 3 & 4 and 6 & 5 \\
\hline \multirow[t]{2}{*}{ PS } & 30 & 50 & 8 & 2000 & $0 \cdot 04$ & 8 & 0.02 & 2000 & 2000 \\
\hline & 45 & 31 & 0.04 & 0.02 & 0.04 & 8 & 0.02 & 2000 & 2000 \\
\hline \multirow[t]{2}{*}{ R5 } & 30 & 52 & 40 & 3000 & 0.04 & 40 & 0.02 & 2000 & 3000 \\
\hline & 45 & 35 & 40 & 3000 & 0.04 & 40 & 0.02 & 2000 & 3000 \\
\hline \multirow[t]{2}{*}{ R20 } & 30 & 60 & 60 & 4000 & 0.04 & 60 & 0.02 & 2000 & 4000 \\
\hline & 45 & 40 & 60 & 4000 & 0.04 & 60 & 0.02 & 2000 & 4000 \\
\hline \multirow[t]{2}{*}{ R40 } & 30 & 60 & 80 & 4000 & 0.04 & 80 & 0.02 & 2000 & 4000 \\
\hline & 45 & 40 & 80 & 4000 & 0.04 & 80 & 0.02 & 2000 & 4000 \\
\hline \multirow[t]{2}{*}{$\operatorname{Rev} 14$} & 30 & 54 & 0.01 & 0.01 & 0.04 & - & 0.02 & 2000 & - \\
\hline & 45 & 36 & 0.01 & 0.01 & 0.04 & - & 0.02 & 2000 & - \\
\hline
\end{tabular}

* Determined in vivo by binding with non-radioactive antibiotic and saturating with labelled penicillin as described in the legend to Fig. 1. The concentration is the minimum that caused complete disappearance of PBP from the fluorograms. All other PBPs of the mutants were saturated by the same benzylpenicillin concentrations that saturated the parent PBPs. PBP 5 was not synthesized by strain Rev 14.

† PBP 1 was saturated by the same concentration of cefotaxime in strain PS and in the mutants.

In the in vivo PBP binding experiments described above bacteria were incubated with $\beta$ lactams for $60 \mathrm{~min}$, a time that in some micro-organisms might be sufficient to cause cell lysis particularly when concentrations above the MIC are used. However, S. faecium has proved to be rather resistant to lysis by both benzylpenicillin and cefotaxime. In fact concentrations of 


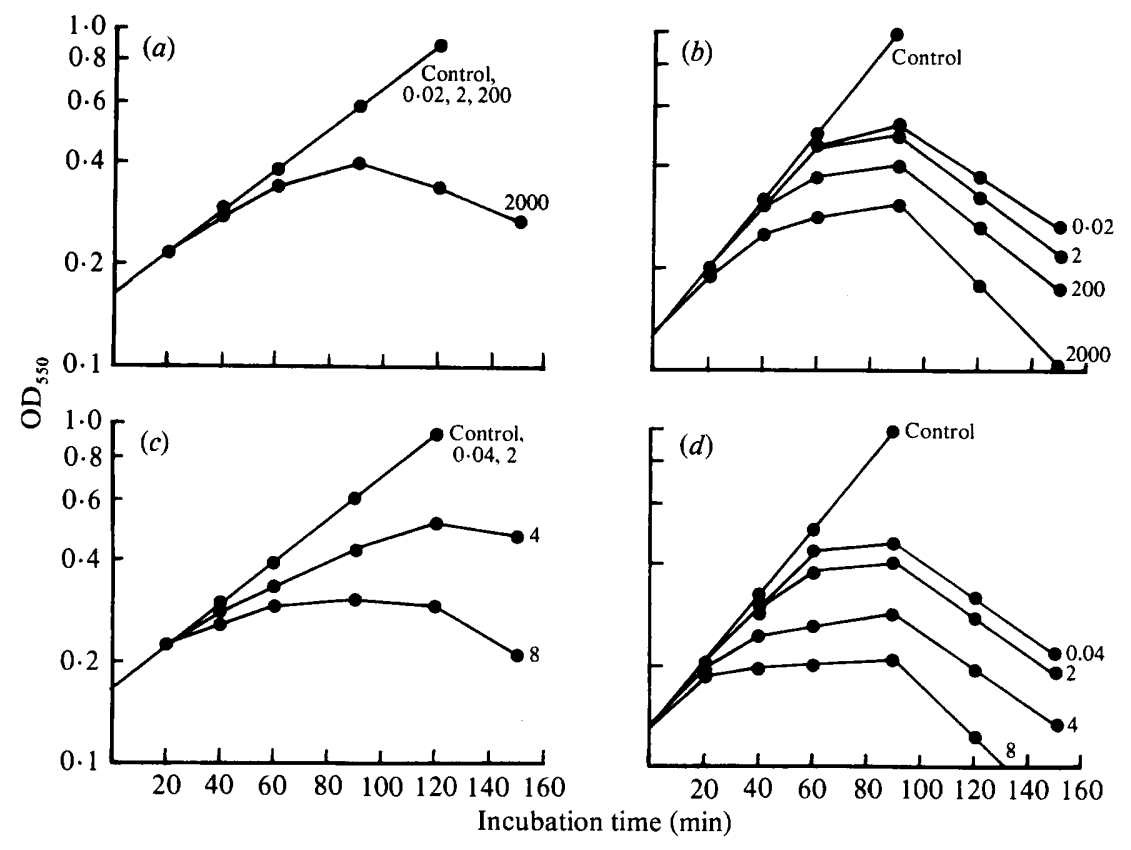

Fig. 3. Effect of cefotaxime and benzylpenicillin on the growth of $S$. faecium. Cefotaxime $(a, b)$ and benzylpenicillin $(c, d)$ were added at various concentrations to exponentially growing cultures at zero time and the cultures were incubated at $30^{\circ} \mathrm{C}(a, c)$ and $45^{\circ} \mathrm{C}(b, d)$. The optical density of the cultures was monitored at $550 \mathrm{~nm}$. Untreated cultures were used as controls. The numbers by the curves are the antibiotic concentrations $\left(\mu \mathrm{g} \mathrm{ml}^{-1}\right)$.

Table 3. Susceptibility to benzylpenicillin and PBP saturation of S. faecium PS incubated at $37^{\circ} \mathrm{C}$ in different media

$\begin{array}{lcccc}\text { Medium } & \begin{array}{c}\text { Generation } \\ \text { time (min) }\end{array} & \begin{array}{c}\text { MIC } \\ \left(\mu \mathrm{g} \mathrm{ml}^{-1}\right)\end{array} & \overbrace{\text { MIC }}^{\begin{array}{c}\text { PBPs saturated by } \\ \text { penicillin at: }\end{array}} \\ \text { SB } & 26 & 0 \cdot 25 & 2 \text { and } 3 & \frac{1}{2} \mathrm{MIC} \\ \text { SB diluted sixfold } & 61 & 8 & \text { All } & \text { All, except } 5\end{array}$

benzylpenicillin up to $8 \mu \mathrm{g} \mathrm{ml}^{-1}$ and concentrations of cefotaxime up to $2000 \mu \mathrm{g} \mathrm{ml}^{-1}$ at both 30 and $45^{\circ} \mathrm{C}$ allowed the optical density of the culture to increase for at least $90 \mathrm{~min}$ (Fig. 3). The rate of increase in the optical density decreased as the antibiotic concentration increased, but was, in all cases, clearly evident (Fig. 3).

In the experiments described above different growth rates were obtained by changing the temperature of incubation. To exclude the possibility that the different susceptibilities observed under the different conditions of growth could be direct effect of temperature and not related to the growth rate, we evaluated both the penicillin MIC and the binding of the antibiotic to PBPs in $S$. faecium growing in different media at the same temperature. In SB medium incubated at $37^{\circ} \mathrm{C}$ the generation time of $S$. faecium was $26 \mathrm{~min}$, whereas in diluted SB incubated at the same temperature it was $61 \mathrm{~min}$ (Table 3). The susceptibility to $\beta$-lactams was higher in fast growing cells than in slow growing cells whereas the affinity of PBPs for $\beta$-lactams did not change. These findings also show that when $S$. faecium cells are incubated at the same temperature in media that permit growth at different rates, different concentrations of $\beta$-lactams are required to inhibit growth, which is consistent with the interpretation that the inhibition of different PBPs is responsible for growth inhibition at fast and slow rates. 


\section{DISCUSSION}

These studies show that the PBPs which must bind and be saturated, either by benzylpenicillin or by cefotaxime, to cause growth inhibition are different in fast and slow growing cells. This finding demonstrates that in wild-type $S$. faecium different PBPs are essential in fast growing cells and in cells growing at a reduced rate and indicates that a PBP does not necessarily fulfil the same role under all conditions but that its function depends on the physiological status of the cells, as previously suggested (Fontana et al., 1983 a). Such a finding has implications for understanding the functions of PBPs in cell physiology and the way in which their activity is regulated. It is possible also that in other micro-organisms PBPs that are indispensable under some growth conditions may become dispensable under other growth conditions.

The competition experiments with non-radioactive benzylpenicillin have shown that PBP 3 (and possibly 1 and 2) activity is necessary in fast growing cells, while PBP 5 alone is sufficient for cell growth at a reduced rate. Previously (Fontana et al., 1983b) we showed that enhanced amounts of PBP 5 can take over the functions of all other PBPs, even at the maximal growth rate (Table 2). Other authors have shown that $\beta$-lactam resistant Staphylococcus aureus strains overproduce a PBP which allows the cells to grow in the presence of $\beta$-lactam concentrations which saturate all other PBPs (Wyke et al., 1982; Hartman \& Tomasz, 1984). However it must be stressed that the case we describe in this paper is rather different since it involves a normal wild-type strain in which one of the PBPs becomes the only essential one during growth at submaximal rates. Since this PBP has a much lower affinity for $\beta$-lactams than the other PBPs, the growth conditions under which PBP 5 alone is essential for cell growth cause a shift in the target for the inhibitory action of $\beta$-lactams. This may explain the fact that susceptibility of $S$. faecium to $\beta$-lactams is greatly influenced by changes in growth conditions (Fontana et al., 1983a; Hinks et al., 1977). A similar explanation could also apply to other bacteria whose sensitivity to $\beta$ lactams is influenced by their growth rate (Annear, 1968; Thrupp, 1980).

We proposed previously (Fontana et al., 1983a) that the mechanism of growth inhibition by $\beta$ lactams is indirect and not constant and depends on which PBP is indispensable and the affinity of this protein for these antibiotics. The results reported here that the PBP target for $\beta$-lactam inhibitory activity changes according to the physiological status of the cells and that this change is associated with a change in sensitivity to such antibiotics strongly support our previous proposal.

We thank Stephen Raffanti for his help in preparing the manuscript and Pietro Cavo, whose technical assistance has been greatly appreciated. We are very much indebted to Patrick J. Cassidy of Merck \& Co., Inc., Rahway, NY, USA, for the generous gift of $\left[{ }^{3} \mathrm{H}\right]$ benzylpenicillin.

This work was supported by grants 83.00375 .04 and 83.00694 .52 from the Consiglio Nazionale delle Ricerche (Italy).

\section{REFERENCES}

ANNEAR, D. J. (1968). The effect of temperature on resistance of Staphylococcus aureus to methicillin and some other antibiotics. Medical Journal of Australia 52, 444-446.

Brown, F. J. \& ReYNolds, P. E. (1980). Intrinsic resistance to beta-lactam antibiotics in Staphylococcus aureus. FEBS Letters 122, 275-278.

Coyette, J., Somzè, A., Briquet, J. J., Ghuysen, J. M. \& FontanA, R. (1983). Function of penicillin binding protein 3 in Streptococcus faecium. In The Target of Penicillin, pp. 523-530. Edited by $\mathrm{R}$. Hakenbeck, J. V. Holtjie \& H. Labishinski. Berlin: Walter De Gruyter \& Co.

Eliopoulos, G. M., Wennersten, G. \& Moellering, R. C. (1982). Resistance to beta-lactam antibiotics in Streptococcus faecium. Antimicrobial Agents and Chemotherapy 22, 295-301.
Fontana, R., Canepari, P., Satta, G. \& Coyette, J. (1980). Identification of the lethal target of benzylpenicillin in Streptococcus faecalis by in vivo penicillin binding studies. Nature, London 287, 70-72.

Fontana, R., Canepari, P., Satta, G. \& Coyette, J. (1983a). Streptococcus faecium ATCC 9790 penicillin binding proteins and penicillin sensitivity are heavily influenced by growth conditions; proposal for an indirect mechanism of growth inhibition by betalactams. Journal of Bacteriology 154, 916-923.

Fontana, R., Cerini, R., Longoni, P., Grossato, A. \& CANEPARI, P. (1983b). Identification of a streptococcal penicillin binding protein that reacts very slowly with penicillin. Journal of Bacteriology 155, 1343-1350.

Fontana, R., Grossato, A., Rossi, L., Cheng, Y. R. \& SATTA, G. (1985). Transition from resistance 
to hypersusceptibility to beta-lactam antibiotics associated with loss of low affinity penicillin-binding protein in a Streptococcus faecium mutant highly resistant to penicillin. Antimicrobial Agents and Chemotherapy 28, 678-683.

Giles, A. F. \& ReYNolds, P. E. (1979). Bacillus megaterium resistance to cloxacillin accompanied by a compensatory change in penicillin binding proteins. Nature, London 280, 167-168.

HaRtman, B. J. \& Tomasz, A. (1984). Low-affinity penicillin binding protein associated with betalactam resistance in Staphylococcus aureus. Journal of Bacteriology 158, 513-516.

Hinks, E. T., Daneo-Moore, L. \& Braverman, S. (1977). Temperature effects on minimum inhibitory and bactericidal concentrations of cell wall antibiotics in Streptococcus faecalis. Antimicrobial Agents and Chemotherapy 12, 281-283.

Matsuhashi, M., Ishino, F., Tamaki, S., NakajiamaIjima, S., Tomioka, S., NagakaWa, J., Hirata, A., SPRATT, B. G., Tsuruoka, T., INOUYe, S. \& Yamada Y. (1982). Mechanism of action of beta-lactam antibiotics. Inhibition of peptidoglycan transpeptidases and novel mechanisms of action. In Trends in Antibiotics Research: Genetics, Biosyntheses, Actions and New Substances, pp. 99-114. Edited by $\mathrm{H}$. Umezawa, A. Demain, T. Hata \& C. R. Hutchinson. Tokyo: Japan Antibiotics Research Association.

Shockman, G. D. (1963). Aminoacids. In Analytical
Microbiology, pp. 567-573. Edited by F. Kavanagh. New York: Academic Press.

SPRATT, B. G. (1975). Distinct penicillin binding proteins involved in the division, elongation and shape of Escherichia coli K12. Proceedings of the National Academy of Sciences of the United States of America 72, 2999-3003.

Suzuki, A., Nishimura, Y. \& Hirota, Y. (1978). On the process of cellular division in Escherichia coli: a series of mutants of $E$. coli altered in the penicillin binding proteins. Proceedings of the National Academy of Sciences of the United States of America 75, 664-668.

THRUPP, L. D. (1980). Susceptibility testing of antibiotics in liquid media. In Antibiotics in Laboratory Medicine, pp. 73-113. Edited by V. Lorian. Baltimore: Williams \& Wilkins.

Tomasz, A. (1979). The mechanism of the irreversible antimicrobial effects of penicillins: how the betalactam antibiotics kill and lyse bacteria. Annual Review of Microbiology 33, 113-137.

Waxman, D. J. \& Strominger, J. L. (1983). Penicillin binding proteins and the mechanism of action of beta-lactam antibiotics. Annual Review of Biochemistry 52, 825-869.

WYKe, A. W., WARD, J. B. \& HaYes, M. W. (1982). Synthesis of peptidoglycan in vivo in methicillin resistant Staphylococcus aureus. European Journal of Biochemistry 127, 553-558. 